\title{
Development of Learning Media Based on Smart Apps Creator
}

\author{
Khasanah 1, Rusman' \\ DOI: 10.35445/alishlah.v13i2.549
}

\section{Info Artikel \\ Abstract}

Keywords:

Development;

Learning Media;

Smart Apps Creator;

Kata kunci:

Pengembangan;

Media Pembelajaran;

Smart Apps Creator
The presence of technology should be able to penetrate the limitations of space and time in improving the quality of learning. This study aims to develop learning media for Smart Apps Creator (SAC), determine the level of Validity and Reliability of Smart Apps Creator (SAC) media products, and determine the efficiency of Smart Apps Creator (SAC) media products. This research was conducted at SMK Sandikta Bekasi City. This research method uses the ADDIE model approach which has five steps, namely Analyze, Design, Develop, Implement, and Evaluate. The development of media based on Android Smart Apps Creator (SAC) uses Al-Quran material as a way of life. The validation of this development product was carried out by three media experts and three material experts and continued with a one-on-one trial of three students and a small group trial of three people. The results of the research and development that have been carried out have produced a physical model of learning media products based on Android SAC (Smart Apps Creator). The results of the validation of the validators stated that the media was suitable for use in class XI SMK students. With the respective eligibility rates of $85 \%$ and $83 \%$. SAC product efficiency The development of SAC media has been effective but not yet maximized. This is due to the limited hosting capacity to accommodate all materials and materials that are more complex. This can be seen from the effectiveness test of $58 \%$ pre-test and $86 \%$ post-test, so there is an average difference of $28 \%$.

\begin{abstract}
Abstrak
Kehadiran teknologi sudah sepantasnya dapat menembus keterbatasan ruang dan waktu dalam peningkatan kualitas pembelajaran. Penelitian ini bertujuan untuk mengembangkan media pembelajaran Smart Apps Creator (SAC), mengetahui tingkat Validitas dan Reabilitas produk media Smart Apps Creator (SAC), dan untuk mengetahui efesiensi produk media Smart Apps Creator (SAC). Penelitian ini dilaksanakan di SMK Sandikta Kota Bekasi. Metode penelitian ini menggunakan pendekatan model ADDIE yang memiliki lima langkah yaitu Analyze, Design, Develop, Implement, and Evaluate. Pengembangan media berbasis android Smart Apps Creator (SAC) menggunakan materi Al-Quran sebagai pedoman hidup. Validasi terhadap produk pengembangan ini di lakukan oleh tiga ahli media dan tiga ahli materi serta dilanjutkan uji coba satu-satu sebanyak tiga orang siswa dan uji coba kelompok kecil juga sebanyak tiga orang. Hasil Penelitian dan pengembangan yang telah dilakukan menghasilkan model fisik produk media pembelajaran berbasis Android SAC (Smart Apps Creator). Hasil validasi para validator menyatakan media layak digunakan pada siswa kelas XI SMK. Dengan tingkat kelayakan masing-masing adalah 85\% dan 83\%. Efisiensi
\end{abstract}

${ }^{1}$ Universitas Islam As-Syafi'iyah, Jakarta, Inonesia

Email: khasanah12031971@gmail.com

${ }_{2}$ Universiatas Islam As-Syafi'iyah, Jakarta, Indonesia

Email: rusmanislam.muna@gmail.com 
produk SAC Pengembangan media SAC sudah efektif namun belum maksimal. Hal tersebut dikarenakan keterbatasan kapasitas hosting untuk menampung seluruh materi dan bahan yang lebih kompleks. Hal tersebut terlihat dari uji efektifitas hasil belajar pre-test $58 \%$ dan post-test adalah $86 \%$, sehingga ada perbedaan rata-ratanya senilai $28 \%$.

\section{PENDAHULUAN}

Peningkatan mutu pendidikan akan memberi sumbangan kepada bertambah tingginya tingkat kualitas manusia Indonesia, yang gilirannya akan berimbas kepada pembangunan itu sendiri. Pengajaran yang dilaksanakan di sekolah harus menjamin peserta didik untuk meningkatkatkan potensi diri mereka, sehingga akan menjadikan peserta didik dapat mengembangkan diri, termasuk kemampuan berpikir (Khasanah, 2016).

Model pembelajaran yang kreatif dan inovatif tentu sangat perlu dikembangkan untuk meningkatkan efektivitas dan efisiensi pembelajaran. Apapun penghambat terjadinya transfer of knowledge harus di minimalisir, termasuk hal-hal yang membuat proses pembelajaran menjadi kurang menarik, monoton sehingga membosankan (Fadhli, 2015). Peran media dalam proses pembelajaran menjadi penting, sebagaimana yang diungkapkan oleh Muhson bahwa media pembelajaran dapat membantu peserta didik dalam mencerna dan memahami materi pelajaran karena fungsi media tersebut sebagai penyalur pesan dan informasi belajar (Muhson, 2010).

Pemanfaatan yang maksimal teknologi informasi dan komunikasi, membuka sekat-sekat informasi oleh inisiatif kuat individu yang ingin mengetahui lebih jauh terhadap segala sesuatunya. Hal ini di ungkapkan oleh Yusuf bahwa di dunia ini, siapapun dapat memiliki akses terhadap sumber informasi. Masyarakatpun menjadi kritis dan tanggap melihat perkembangan yang ada (Yusuf, 2014). Android dengan potensinya yang begitu besar, membuat sistem operasi android melesat cepat dan menarik perhatian para pengembang aplikasi. Android kini ada di tangan guru dan murid dan dapat menjadikan dia sebagai media pembelajaran tentunya. Ismanto menegaskan bahwa pengembangan beragam aplikasi Android sebagai aplikasi social networking hingga aplikasi untuk belajarpun dilakukan oleh para pengembang Android (Ismanto et al., 2017).

Media pembelajaran yang berbasis aplikasi android mempunyai beberapa keunggulan, seperti halnya yang diungkapkan oleh Hakim antara lain praktis saat dibawa, terhubung ke jaringan kapan dibutuhkan dan di mana saja selama ada akses ke wifi atau kabel data yang cukup, fleksibel saat mengakses sumber belajar, komunikasi lebih dekat, terlibat dan aktif para siswa. Harga yang terjangkau juga menjadikan keunggulan utamanya (Hakim, 2018). Kemudahan dalam membuat aplikasi edukatif juga telah mendapat dukungan dari beberapa pihak. Pesan pembelajaran dapat tersimpan pada ingatan jangka panjang orang yang mempelajarinya karena media pembelajaran berbasis android dapat dirancang dengan pendekatan visual yang maksima (Prasetyo, 2017).

Berdasarkan pernyataan Hakim dan Prasetyo tersebut, peneliti melakukan pengembangan media berbasis Android ini, karena sangat membantu siswa dalam memilih alternatif media pembelajaran. Smart Apps Creator 3 (SAC) merupakan aplikasi desktop untuk membuat aplikasi mobile android dan iOS tanpa kode pemrograman, serta dapat menghasilkan format HTML5 dan .exe. Peningkatkan kreatifitas siswa dalam mengelola konten dan aplikasi-aplikasi mobile menarik lainnya dapat di lakukan.

Langkah awal membuat konten produk adalah merumuskan unsur-unsur dan bahan ajar yang mencakup tujuan, sasaran, uraian materi, sistematika sajian, petunjuk belajar dan evaluasi. Tujuan tentu dirumuskan secara jelas dan terukur, dapat menggunakan kriteria ABCD (audience, behavior, criterion, dan degree). Sasaranpun dirumuskan secara spesifik, untuk siapa bahan ajar itu ditujukan, kemampuan prasyarat yang harus dimiliki siswa, sehingga tepat sasaran.

Kelengkapan fitur yang dapat dikembangkan di dalam media SAC berbasis Android ini juga menjadi alasan penguat kami mengembangkan produk SAC ini. Sebagaimana yang diungkapkan oleh Purnama seorang praktisi sekaligus staff BPMPK Semarang (2019) komponen atau konten 
mobile learning sangatlah berbeda-beda, namun secara global yang paling mudah untuk penggunaan media pembelajran adalah sistem Smart Apps Creator (SAC), penggunaan aplikasi ini sangatlah mudah dioperasikan dan digunakan tanpa harus menggunakan coding atau HyperText Markup Language yang disingkat dengan HTML.

Peneliti memilih mengembangkan SAC ini di Sekolah Menengah Kejuruan (SMK), karena proses pembelajaran dilaksanakan secara interaktif, penuh tantangan dan memotivasi siswa untuk mandiri dan peduli terhadap mata pelajaran, sebagaimana yang di ungkapkan oleh (Pribadi, 2017). Penelitian pengembangan produk SAC ini berharap agar proses pembelajaran dengan menggunakan media SAC ini mendorong kreaktivitas siswa dalam rangka meningkatkan penguasaan pengetahuan, pemahaman dan keterampilan. Peningkatan hasil belajar dengan menggunakan media SAC ini perlu di lakukan uji efektifitas penggunaan media SAC ini. Hal ini sebagaimana hasil penelitian terdahulu oleh Budiningsih dan Lubis yang menyatakan bahwa perlu di lakukan penilaian sehingga terlihat seberapa jauh penguasaan sejumlah pengetahuan siswa untuk mengetahui penguasaan suatu bahan pelajaran siswa. Melihat perbedaan yang signifikan antara hasil yang diinginkan/direncanakan dengan dengan kenyataan dilapangan, maka dilakukanlah evaluasi (Budiningsih \& Lubis, 2018).

Dengan adanya pembelajaran berbasis SAC yang berisi slide presentasi, video pendukung dan materi yang relevan serta penugasan diharapkan dapat memberikan kemudahan bagi pemakai khususnya siswa dalam proses belajarnya. Dan tentu guru pun harus terus mendorong siswa agar kooperatif memanfaatkan semua fitur yang disediakan dalam media pembelajaran Android Smart Apps Creator (SAC).

Penelitian Pengembangan Produk E-learning sebelumnya oleh Irawan \& Surjono (2018) Menghasilkan media e-learning pada mata pelajaran bahasa Inggris berbasis Moodle, layak digunakan dalam peningkatan listening skill. Widodo \& Mukminan (2018) menyatakan bahwa kelayakan media e-learning masuk dalam kriteria sangat baik. Dapat dilihat dari rerata N-gain kelas eksperimen dan kelas kontrol. Terlihat perbedaan hasil belajar antara kelas eksperimen dan kelas kontrol setelah pembelajaran. Terdapat juga perbedaan kemandirian belajar antara kelas eksperimen dan kelas kontrol setelah pembelajaran, kelas eksperimen yang menggunakan media eLearning lebih tinggi hasil belajarnya. Peneliti melakukan penelitian pengembangan media pembelajaran e-learning jenis lainnya, dalam hal ini yang berbasis Android Smart Apps Creator dalam upaya menunjang proses pembelajaran, khususnya di bidang Pendidikan Agama Islam (PAI). Penelitian ini dikembangkan untuk menjawab rumusan masalah penelitian tentang pengembangan media pembelajaran berbasis Android Smart Apps Creator pada mata pelajaran PAI, validitas dan reabilitas media pembelajaran Android Smart Apps Creator pada mata pelajaran PAI, dan tingkat efesiensi produk media pembelajaran Android Smart Apps Creator pada mata pelajaran PAI.

\section{METODE}

Jenis penelitian ini adalah penelitian pengembangan (R\&D) dengan model pengembangan yang digunakan yaitu model ADDIE. ADDIE adalah singkatan dari Analysis, Design, Development, Implementation, and Evaluation. Penelitian pengembangan model pembelajaran dan media pembelajaran banyak menggunakan model ADDIE (Muslimin, Nordin, \& Mansor, 2017). Penelitian jenis pengembangan lebih memilih menggunakan model ADDIE karena menghasilkan produk dan bermanfaat meningkatkan hasil belajar siswa (Martin, Hoskins, Brooks, 2013).

Tahapan ADDIE adalah: 1). Analyze, yaitu melakukan analisis kebutuhan, mengidentifikasi masalah, dan melakukan analisis tugas. 2). Design, atau lebih dikenal dengan tahap rancangan: perumusan tujuan pembelajaran, penyusunan tes, penentuan strategi pembelajaran yang tepat. 3). Develop, dalam tahap ini kegiatan yang dilakukan adalah perancangan yang menghasilkan produk pembelajaran berbasis Android Smart Apps Creator (SAC). 4) Implement, tahap ini merupakan tindakan nyata untuk pemakaian Android Smart Apps Creator. 5) Evaluation, Evaluasi atau penilaian yang mencakup; tujuan, perancangan dan pengembangan instrumen, pengumpulan data, analisis dan penafsiran untuk menentukan suatu nilai dengan standar penilaian yang telah 
ditentukan. Untuk melihat apakah terdapat berbedaan yang signifikan antara hasil yang diinginkan/direncanakan dengan dengan kenyataan dilapangan maka dilakukan evaluasi/penilaian (Budiningsih\& Lubis, 2018).

Adapun penelitian dan pengembangan media SAC dilakukan di lingkungan Sekolah Menengah Kejuruan Sandikta kota Bekasi, siswa kelas XI SMK. Hal ini dimaksudkan untuk mendorong kemajuan dan kemandirian belajar siswa dalam pemanfaatan media berbasis Adroid.

Pengumpulan data penelitian melalui: 1) Wawancara atau interview. Digunakan peneliti pada tahap awal penelitian pengembangan yaitu untuk mengidentifikasi berbagai potensi dan masalah yang perlu dikaji dalam penelitian ini. Wawancara dilakukan pada dua sumber, yaitu guru mata pelajaran Pendidikan Agama Islam (PAI) dan siswa kelas XI. Kegiatan wawancara dilakukan tidak terstruktur, dimana tidak disiapkan instrument secara sistematik. Pedoman wawancara yang digunakan hanya berupa garis-garis besar permasalahan yang akan ditanyakan. 2) Pengamatan atau observation merupakan metode pengumpulan data yang dilakukan dengan jalan melakukan pengamatan. Amatan untuk mengetahui secara langsung berbagai hal yang berkaitan dengan pelaksanaan pembelajaran. Aspek yang diamati meliputi penggunaan media pembelajaran, metode pembelajaran, karakteristik awal siswa serta lingkungan tempat belajar siswa. 3). Angket atau questioner yang disebarkan kepada seluruh responden digunakan untuk memperoleh informasi dalam arti laporan tentang data pribadi. Angket dipergunakan untuk mengevaluasi dan mengetahui kelayakan produk, 4). Instrumen penilaian kelayakan media, untuk mengevaluasi dan mengetahui kelayakan dari media. Instrumen tersebut dibagi menjadi tiga kelompok yaitu; a) untuk ahli materi, b) untuk ahli media, diberikan pada pada 3 validator ahli masing-masingnya. dan c) untuk pengguna atau siswa, diberikan di awal untuk mengetahui analisis kebutuhan produk dan di akhir untuk uji coba produk pada siswa yang berbeda.

Validasi Instrumen yang digunakan untuk penilaian validitas kelayakan produk juga perlu di lakukan. Diberikan sebelum instrumen angket validasi diberikan kepada ahli media dan ahli materi. instrumen tersebut terlebih dahulu dilakukan validasi oleh para validator. Baik validator bahasa , validator konten. atau validator konstruk. Hal ini di lakukan untuk mengukur apakah instrumen validasi tersebut sudah layak diberikan kepada para validator materi dan media. Para validator menilai instrument dengan mengisi sejumlah rubrik, kemudian di rata-ratakan hasil yang diperoleh dari beberapa ahli. Ketika instrumen angket tersebut dikatakan layak oleh validator maka selanjutnya peneliti menyerahkan instrumen validasi produk tersebut kepada kedua ahli tersebut. untuk menemukan sejauh mana produk hasil pengembangan tersebut, diujicobakanlah kepada target penelitian. Berikut format penilaian validasi angket:

Tabel 1. Validasi Instrumen Angket Validitas Kelayakan Produk

\begin{tabular}{|c|c|c|}
\hline Aspek & Indikator & Skala Penilaian \\
\hline \multirow[t]{3}{*}{ Kejelasan } & 1. Kejelasan judul lembar angket & \\
\hline & 2. Kejelasan butir pernyataan & \\
\hline & 3. Kejelasan petunjuk pengisian angket & \\
\hline $\begin{array}{l}\text { Ketepatan } \\
\text { Isi }\end{array}$ & $\begin{array}{l}\text { 4. Ketepatan pernyataan dengan jawaban yang } \\
\text { diharapkan }\end{array}$ & \\
\hline \multirow[t]{2}{*}{ Relevansi } & 5. Pernyataan berkaitan dengan judul penelitian & \\
\hline & $\begin{array}{l}\text { 6. Pernyataan sesuai dengan aspek yang ingin } \\
\text { dicapai }\end{array}$ & \\
\hline $\begin{array}{l}\text { Kevalidan } \\
\text { Isi }\end{array}$ & $\begin{array}{l}\text { 7. Pernyataan mengungkapkan informasi yang } \\
\text { benar }\end{array}$ & \\
\hline $\begin{array}{l}\text { Tidak Ada } \\
\text { Bias }\end{array}$ & 8. Pernyataan berisi satu gagasan yang lengkap & \\
\hline \multirow{3}{*}{$\begin{array}{l}\text { Ketepatan } \\
\text { Bahasa }\end{array}$} & 9. Bahasa yang digunakan mudah dipahami & \\
\hline & 10. Bahasa yang digunakan efektif & \\
\hline & 11. Penulisan sesuai dengan EYD & \\
\hline
\end{tabular}


Adapun instrumen yang digunakan dalam penelitian ini berupa angket (questionnaire). Angket tersebut berisi pernyataan atau pertanyaan yang disusun berdasarkan konstruksi teoritik yang telah disusun sebelumnya, kemudian dikembangkan menjadi beberapa indikator dan selanjutnya dijabarkan menjadi butir-butir pernyataan atau pertanyaan. Jenis angket yang digunakan yaitu angket tertutup dalam bentuk check list, dimana responden hanya memberikan tanda check list $(\sqrt{ })$ pada kolom jawaban yang telah disediakan. Jawaban yang disediakan berupa jawaban bergradasi dari sangat positif sampai sangat negatif. Sedangkan skala pengukaran yang digunakan adalah skala likert, dengan skala 1 sampai 5. Skala ini digunakan untuk mengukur persepsi dan pendapat responden terhadap produk media pembelajaran yang dikembangkan. Skor yang didapat melalui skala likert ini pada instrumen penilaian, digunakan untuk mengevaluasi dan mengetahui kelayakan dari media pembelajaran yang dikembangkan. Instrumen tersebut dibagi menjadi tiga kelompok peruntukannya; 1) validator materi, 2) validator media, dan 3) pengguna atau siswa.

Ahli materi menilai media pembelajaran ditinjau dari aspek kualitas isi materi yang ada dalam media pembelajaran dan kualitas pembelajaran. Kualitas isi materi meliputi aspek ketepatan isi materi, kelengkapan isi materi, urutan isi materi. Aspek Kualitas pembelajaran terdiri dari relevansi tujuan pembelajaran, Ketepatan penggunaan startegi pembelajaran, pemberian dampak positif bagi guru, kejelasan tujuan isi materi, kesiapan isi materi, penilaian isi materi.

Ahli media menilai media berkaitan dengan aspek-aspek yang berhubungan dengan media pembelajaran, yaitu:

1) Aspek kualitas isi dengan indikator yang dinilai adalah penggunaan media gambar/animasi, penggunaan navigasi, kelengkapan penggunaan audia (musik/suara), penggunaan media gerak (animasi), kemudahan dalam mengeksekusi media pembelajaran, ketepatan memilih jenis software untuk pengembangan media pembelajaran.

2) Aspek kualitas pembelajaran dengan indikator yang dinilai adalah : kejelasan dan kelengkapan petunjuk penggunaan media pembelajaran, kemudahan dalam memelihara dan pengelolaan media pembelajaran, ketepatan memilih jenis software untuk pengembangan media pembelajaran, dan kualitas tes dan penilaian. Adapun rentang penilaian yang digunakan adalah skala 1-5.

Instrumen untuk siswa digunakan untuk mengetahui kelayakan media pembelajaran di lihat dari sudut pandang siswa. Aspek-aspek yang dinilai meliputi kualitas isi materi, kualitas pembelajaran, komunikai visual dan rekayasa perangkat lunak. Teknik analisis data yang digunakan adalah statistik deskriptif kualitatif yang digunkan untuk menganalisis data dengan cara menjelaskan data yeng telah terkumpul tanpa bermaksud membuat kesimpulan yang berlaku untuk umum atau generalisasi. Adapun teknik analisis data yang digunakan pada penelitian ini yaitu:

1) Analisis data ahli materi

2) Analisis data ahli media

3) Analisis data evaluasi siswa

4) Teknik analisis data uji lapangan.

Validasi dilakukan dengan cara memberikan instrumen penilaian media kepada para ahli. Para ahli akan memberikan penilaian dalam instrumen tersebut dan juga memberikan saran perbaikan terhadap media pembelajaran yang telah dikembangkan. Penilaian berupa skala Likert 15 dengan ketentuan nilai 5 adalah sangat baik, nilai 4 adalah baik, nilai 3 adalah cukup baik, nilai 2 adalah kurang baik dan nilai 1 adalah sangat tidak baik.

Berdasarkan nilai yang diberikan oleh para ahli, maka selanjutnya digunakan rumus sebagai berikut :

$$
\text { Nilai Validitas }(v)=\frac{\text { Skor yang diperoleh (f) }}{\text { - Skor Maksimum (n) }}
$$


Selanjutnya nilai akhir dari proses validasi tersebut dikategorikan sesuai nilai persentase dalam tabel kriteria kelayakan media sebagai berikut (Ernawati, 2017) :

Tabel 2. Kriteria Kelayakan Media

\begin{tabular}{ll}
\hline Persentase & Kriteria \\
\hline $81 \%-100 \%$ & Sangat layak \\
\hline $61 \%-80 \%$ & Layak \\
\hline $41 \%-60 \%$ & Cukup layak \\
\hline $21 \%-40 \%$ & Tidak layak \\
\hline$<21 \%$ & Sangat tidak layak \\
\hline
\end{tabular}

Tabel 2 di atas terkait kriteria kelayakan media dan menjadi pedoman bagi peneliti untuk mengkatagorisasikan hasil validasi para ahli dan angket yang diisi siswa.

\section{HASIL PENELITIAN DAN PEMBAHASAN}

\section{Hasil Studi Pendahuluan}

Hasil angket yang diberikan pada siswa tentang pengembangan media pembelajaran berbasis Android SAC (Smart Apps Creator) yang juga wawancara guru mata pelajaran disimpulkan mendapatkan respon dengan baik. Hasil identifikasi kebutuhan pembelajaran melalui siswa sebagai berikut:

1. Hasil uji coba satu-satu (One to One)

Pada tahap ini ada 3 siswa yang menilai analisis kebutuhan produk media pembelajaran berbasis Android Smart Apps Creator (SAC). Penilaian dari ketiga siswa tersebut adalah kualitas isi skornya 57 dan kualitas pembelajaran 59 dan skor maksimalnya adalah 75. Sehingga diperoleh nilai validitas sebagai berikut: $\frac{116}{150}$ x $100 \%=77,3 \%$. Tingkatan Validitas 77,3\% menunjukkan media pembelajaran berbasis Android SAC layak di implementasikan dan di kembangkan.

2. Hasil uji coba kelompok kecil (Small Group)

Peneliti melibatkan 3 orang siswa yang menilai produk media pembelajaran berbasis Android SAC (Smart Apps Creator). Hasil penilaiannya adalah kualitas isi skor yang diperoleh 64 dan sekor maksimal 75, dan kualitas pembelajaran skor yang diperoleh 62 sementara skor maksimalnya juga 75. Sehingga nilai Validitas (v) isi adalah: $\frac{126}{150} \times 100 \%=84 \%$, artinya sangat layak dikembangkan.

Kesimpulannya adalah hasil validasi menunjukkan media sangat layak di kembangkan dengan rata-rata penilaian kelayakan $77,3 \%$ pada uji coba tahap 1 ke siswa dan $84 \%$ pada tahap 2 ke siswa setelah produk di validasi.

\section{Hasil Validasi Ahli/Pakar}

Validasi ini adalah telaah pakar (Expert Judgement) terhadap Pengembangan produk Android Smart Apps Creator (SAC). Validator materi menvalidasi isi materi pembelajaran sesuai dengan indikator yang dikembangkan. Validator media menvalidasi tampilan media desain pembelajaran.

\section{Validitas Ahli Media}

Ahli media yang pertama adalah Dosen sekaligus Kepala Program Studi Magister Teknologi Pendidikan Universitas Islam As-Syafiiyah Jakarta. Adapun skor hasil validasi pada aspek kualitas isi adalah 28 dan kualitas pembelajaran juga 28. Total sekoar yang diperoleh keduanya adalah 56 dan total sekor maksimal adalah 70 dari masing-masing skor maksimal adalah 35 .

Dari data tersebut diperoleh nilai validitas $(v)=56 / 70 \times 100 \%=80 \%$. Nilai validitas media 80 persen, dapat dikatakan bahwa media sangat layak di implementasikan dan di ujicoba pemakaiannya. 
Hasil Validator media ke-2 dari PTP BPMPK Kemendikbud Semarang diperoleh hasil dalam persentase: $\frac{63}{70} \times 100 \%=90 \%$. Artinya media ini sangat layak di implementasikan dan di ujicoba kepada pengguna.

Validator ke-3 selaku PTP ahli media BPMPK Kemendikbud Semarang, melakukan validasi media dengan perolehan hasil validasi: $\frac{61}{70} \times 100 \%=87,1 \%$. Berdasarkan hasil validasi dari ketiga ahli media ketiga di atas maka dapat dikatakan bahwa media pembelajaran berbasis Android SAC (Smart Apps Creator) sangat layak dan dapat di ujicobakan pada pengguna. Tingkat kelayakan ratarata adalah $85 \%$ yang di dapat dari rata-rata validasi ahli materi yaitu $80 \%+90 \%+87,1 \%=85,7 \%$.

Untuk validator ahli materi melibatkan tiga ahli. Validator materi 1 adalah guru produktif TKR SMK Sriwijaya Jakarta, hasil validasi yang diperoleh: $\frac{43}{50}$ x $100 \%=86 \%$ (layak digunakan dan di uji cobakan pada pengguna). Validator materi kedua adalah dari PTP BPMPK Kemendikbud Semarang dengan hasil validasinya adalah: $\frac{41}{50} \times 100 \%=82 \%$ (sangat layak di gunakan dan diujicobakan ke pengguna). Hasil validasi dari Validator materi ke-3 dari Sekolah SDN 16 Parigi adalah : $\frac{40}{50} \times 100 \%=80 \%$ (sangat layak di gunakan dan di ujicobakan ke pengguna).

Dapat disimpulkan bahwa hasil validasi ahli materi terhadap ketepatan isi materi yang mencakup kelengkapan isi materi, kejelasan isi materi, urutan isi materi dari ketiga validator tersebut adalah berada pada tingkatan sangat layak, demikian juga dengan kualitas pembelajaran. Adapun tingkat kelayakan ahli materi adalah sebesar $83 \%$ yang di dapat dari rata-rata persentase $86 \%+82 \%+80 \%=83 \%$, dengan demikian media pembelajaran berbasis Android SAC (Smart Apps Creator) sangat layak di implementasikan dan di ujicoba kepada pengguna.

\section{Respons Pengguna}

Pada tahap respon pengguna, peneliti melibatkan 30 siswa kelas XI SMK Sandikta Kota Bekasi dengan hasil sebagai berikut:

Tabel 3. Validasi Respon Pengguna

\begin{tabular}{lcl}
\hline \multicolumn{1}{c}{ Aspek } & $\begin{array}{c}\text { Skor yang diperoleh } \\
\text { (f) }\end{array}$ & Skor maksimal (s) \\
\hline Kualitas Isi & 627 & 750 \\
\hline Kualitas Pembelajaran & 606 & 750 \\
\hline Jumlah & 1233 & 1500 \\
\hline
\end{tabular}

Dari data tabel 3 di atas diperoleh nilai validitas sebagai berikut: $\frac{1233}{1500}$ x $100 \%=82,2 \%$. Hasil validitas dari respon pengguna (siswa) tersebut menunjukkan media sangat layak di implementasikan.

\section{Pengujian Keefektifan Produk}

Selanjutnya peneliti melakukan post-test kepada seluruh pengguna. Persentase besar pengaruh keefektifan produk adalah selisih dari hasil validasi pre-test dengan post-test yaitu sebesar 28\%. Artinya bahwa pengembangan media pembelajaran berbasis android SAC (Smart Apps Creator) unkuk mata pelajaran Pendidikan agama Islam sudah efektif namun belum maksimal. Hal tersebut dikarenakan terbatasnya ketersediaan hosting menampung seluruh materi.

Pengujian independent sampel test dilakukan dengan menggunakan aplikasi SPSS 21. Berdasarkan tabel ouput statistika diketahui jumlah data pre-test adalah sebanyak 30 orang dan jumlah data post-test sebanyak 30 orang dengan rata-rata pre-test $58 \%$ sementara untuk data post-test adalah $86 \%$. Dengan demikian data deskriptif statistik dapat disimpulkan bahwa ada perbedaan rata-rata antara data pre-test dengan data post-test adalah senilai $28 \%$. Artinya 
bahwa pengembangan media sudah efektif dan layak dikembangkan dan di gunakan pada pengguna.

Hal ini menjadi sebuah solusi dalam pemilihan media pembelajaran, sejalan dengan penelitian lain yang menyatakan : hasil belajar prakarya dan kewirausahaan siswa yang mengikuti model pembelajaran problem based learning lebih unggul daripada siswa yang mengikuti model pembelajaran konvensional (Rahmi dan Khasanah, 2019). Temuan ini menunjukkan bahwa hasil belajar dengan model konvisional tanpa menggunakan media interaktif yang berbasis internet ini, akan lebih rendah hasilnya, apalagi di saat anak-anak sekarang yang terlahir di era native digital. Model-model klasik sudah harus ditinggalkan, guru harus kreatif memnciptakan atau menggunakan hasil-hasil temuan terkini terkait media interaktif ini.

\section{Tahap mendesain susunan flowchat dan storyboard}

Hal ini bertujuan agar dapat menghasilkan alur dan penjelasan tampilan yang sesuai dengan pembelajaran yang berkesinambungan. Diagram alur yang berfungsi sebagai panduan program dan materi, sesuai dengan tujuan pembelajaran disebut flowchart. Setelah tahap pembuatan ini selesai langkah selanjutnya adalah langkah pengembangan yang disebut dengan storyboard, dalam langkah ini peneliti membuat tampilan, animasi, video dan panduan untuk bagian dari materi yang ditampilkan. Dalam proses pembuat media pembelajaran ini dibuat dengan menggunakan program aplikasi Smart Apps Creator (SAC) versi 3.0.

Berdasarkan hasil validasi di atas maka menghasilkan model fisik produk media pembelajaran berbasis Android SAC seperti berikut:

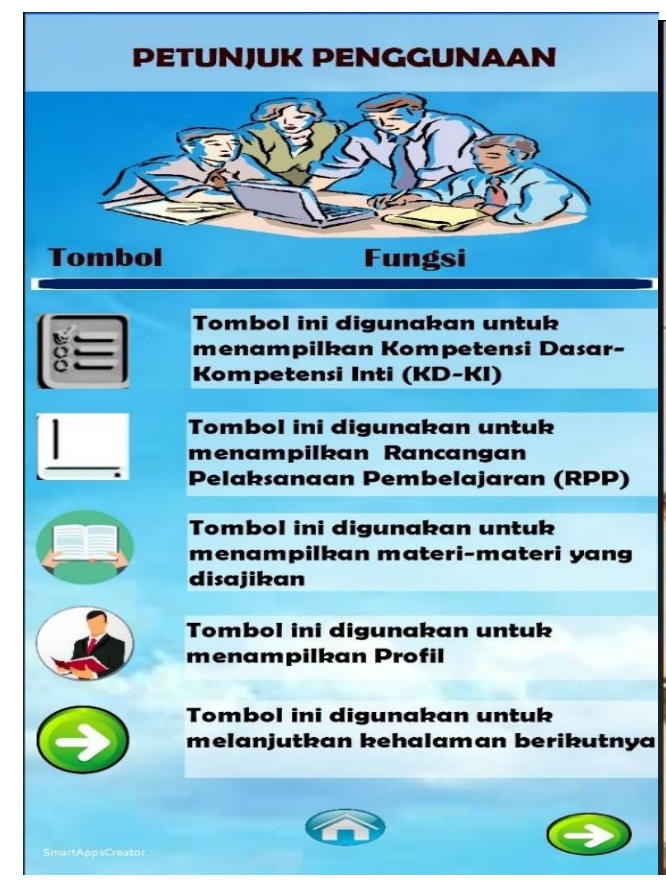

Gambar 1. Petunjuk Penggunaan

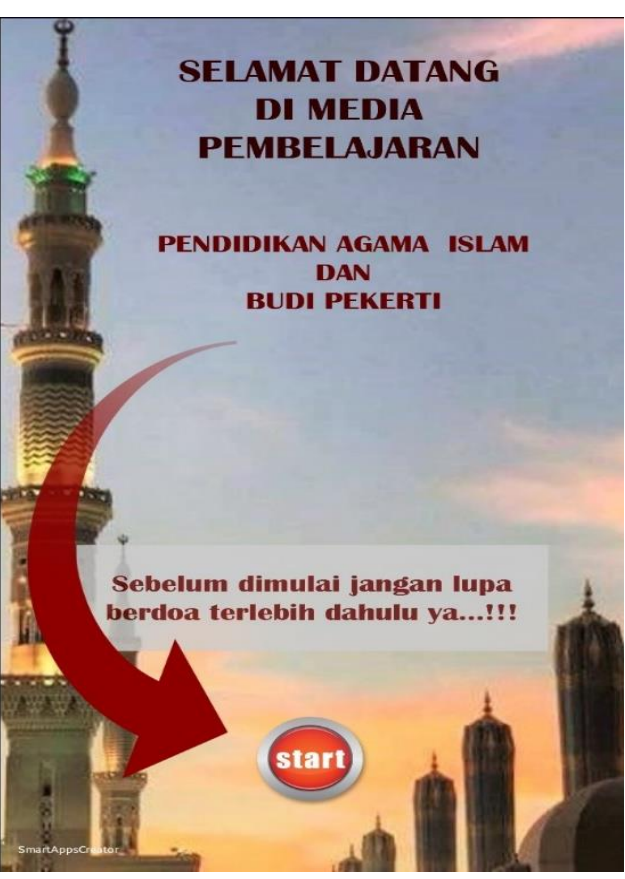

Gambar 2. Tampilan Awal Produk 


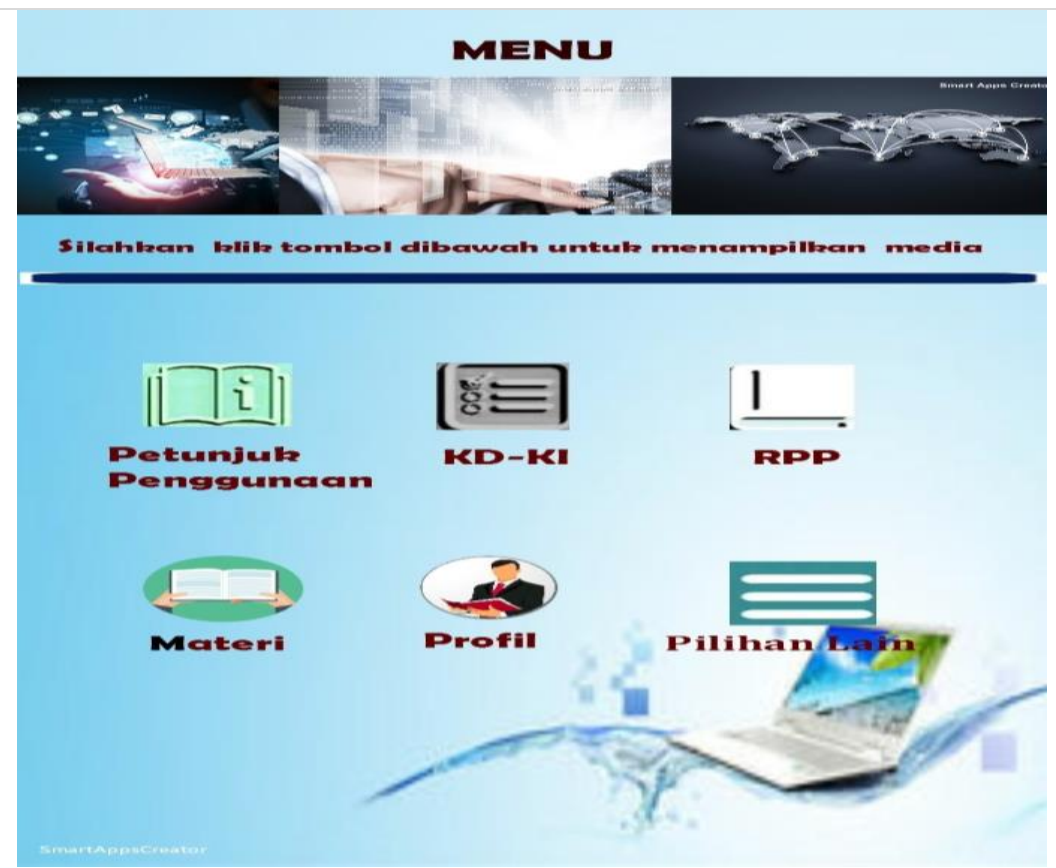

Gambar 3. Tampilan Menu

Berdasarkan tampilan menu produk Gambar 1 di atas terdiri dari enam pilihan yaitu, petunjuk penggunaan, kompetensi dasar dan kompetensi inti (KD-KI), rencana pelaksanaan pembelajaran (RPP), materi, profil dan pilihan lainnya. Untuk lebih jelasnya dapat diuraikan sebagai berikut: 1) Petunjuk penggunaan, bagian produk yang menampilkan petunjuk penggunaan produk, 2) Kompetensi Dasar (KD) dan Kompetensi Inti (KI) yang disesuaikan dengan materi yang ada dalam buku Pendidikan Agama Islam (PAI) kelas XI, 3) Rencana Pelaksanaan Pembelajaran (RPP) juga disesuaikan dengan materi yang ada dalam buku Pendidikan Agama Islam (PAI) kelas XI, 4). Materi, pada tampilan ini adalah pokok bahasan materi pelajaran Pendidikan Agama Islam membahas tentang Al-Quran sebagai pedoman hidup, 5) Menu profil, bagian ini menampilkan profil pengembang, (6) Menu lainnya, pada tampilan ini ada tiga sub menu pilihan yaitu pahala penghafal Al-Quran, rangkuman materi dan soal latihan.

Pengembangan media SAC sangat diperlukan sebagai media interaktif, dapat diakses dimana saja dan kapan saja yang diperlukan. Dengan adanya aplikasi android memungkinkan proses belajar menjadi lebih fleksibel dan interaktif. Belum adanya media interaktif yang disediakan, berdampak pada pengetahuan, pemahaman dan keterampilan siswa rendah. Hal ini menurut Muslih dipengaruhi oleh belum adanya pengetahuan mengenai topik pembelajaran yang diajarkan menyebabkan banyak mengalami kesulitan jika dihadapkan pada praktikum (Muslihah, 2011).

Muhlas dan Murwani dalam temuannya menyatakan bahwa para pengguna produk SAC dapat menggunakan produk ini secara online karena sudah di rancang secara interaktif. Temuan mukhlas dkk juga mengungkapkan bahwa SAC sangat membantu dan memudahkan para karyawan dalam mempromosikan produk di PT Transvision (Muhlas \& Marwani, 2020). Temuan Muhlas sejalan dengan penelitian ini. SAC terbukti efektif digunakan dalam meningkatkan produktifitas, baik hasil belajar maupun peningkatan produktifitas karyawan dalam perusahaan. Apalagi produk Pengembangan media pembelajaran berbasis Android SAC (Smart Apps Creator) telah melalui beberapa tahapan validasi, uji coba dan perbaikan. Revisi produk dilakukan setelah melalui beberapa tahapan uji telaah pakar. Tahap kedua, melakukan uji validasi produk, yaitu melakukan uji validitas konstruk, isi, dan kebahasaan dari produk yang dikembangkan. Azwar dkk menyatakan tentang validitas ini, yaitu sejauh mana ketepatan dan kecermatan suatu pengukur dalam melakukan fungsi ukurnya (Azwar, 2014:8; Santrock, 2010; Rogier, 2014). Validnya produk SAC yang telah kami kembangkan ini serta efesiensi yang terlihat menjadikan SAC ini patut di gunakan 
pada proses pembelajaran di sekolah, aplikasi yang menyediakan konten yang memudahkan siswa dengan tampilannya yang menarik.

\section{SIMPULAN}

Penelitian dan pengembangan yang telah dilakukan menghasilkan model fisik produk media pembelajaran berbasis Android Smart Apps Creator yang layak di gunakan dan di implementasikan. Pengembangan media pembelajaran berbasis Android SAC (Smart Apps Creator) telah melalui beberapa tahapan validasi, uji coba dan perbaikan. Revisi produk dilakukan setelah melalui beberapa tahapan uji telaah pakar, baik pakar media ataupun materi. Selanjutnya di uji coba satusatu dan uji coba kelompok kecil. Dan berdasarkan hasil validator media dan ahli materi serta uji coba pengguna disimpulkan bahwa media Smart Apps Creator dinyatakan layak digunakan dan dikembangkan pada mata pelajaran Pendidikan Agama Islam kelas XI. Kelayakan Terlihat dari tingkat kelayakan validator media adalah $85,7 \%$. dan tingkat kelayakan oleh validator materi sebesar $83 \%$.

Pengembangan media SAC sudah efektif namun belum maksimal. Hal tersebut dikarenakan keterbatasan kapasitas hosting untuk menampung seluruh materi dan bahan yang lebih kompleks. Hal tersebut terlihat dari uji efektifitas hasil belajar pre-test $58 \%$ dan post-test adalah $86 \%$, sehingga ada perbedaan rata-ratanya senilai $28 \%$. Hal ini diharapkan dapat lebih dikembangkan dan ditingkatkan untuk peneliti lain yang akan melakukan penelitian dengan Smart Apps Creator.

\section{DAFTAR PUSTAKA}

Budiningsih I., \& Lubis E. (2019). Quality Evaluation of UIA Academic Cooperation With Partners. Akademika : Jurnal Teknologi Pendidikan, 7(01), 1-16. https://doi.org/10.34005/akademika.v7io1.307

Eneng Muslihah, M. . (2011). Ilmu Pendidikan Islam, Jakarta: Diadit Media.

Ernawati, I. (2017). Uji Kelayakan Media Pembelajaran Interaktif Pada Mata Pelajaran Administrasi Server. Elinvo (Electronics, Informatics, and Vocational Education). 2(2), 204-210. https://doi.org/10.21831/elinvo.v2i2.17315

Fadhli, M. (2015). Pengembangan Media Pembelajaran Berbasis Video Kelas IV Sekolah Dasar. Jurnal Dimensi Pendidikan Dan Pembelajaran, 3(1), 24-28.

Hakim, L. (2018). Pengembangan Media Pembelajaran PAI Berbasis Augmented Reality. Lentera Pendidikan: Jurnal Ilmu Tarbiyah Dan Keguruan, 21(1), 59-72. https://doi.org/10.24252/lp.2018v21n1i6

Irawan, R., \& Surjono, H. D. (2018). Pengembangan E-Learning Berbasis Moodle Dalam Peningkatkan Pemahaman Lagu Pada Pembelajaran Bahasa Inggris. Jurnal Inovasi Teknologi Pendidikan, 5(1), 1-11. https://doi.org/10.21831/jitp.v5i1.10599

Ismanto, E., Novalia, M., \& Herlandy, P. B. (2017). Pemanfaatan Smartphone Android Sebagai Media Pembelajaran Bagi Guru Sma Negeri 2. Jurnal Untuk Mu NegeRI, 1(1), 42-47. https://ejurnal.umri.ac.id/index.php/PengabdianUMRI/article/view/33/14.

Khasanah. (2016). Pengaruh Strategi Pembelajaran Berbasis masalah dan Model Pensekoran Terhadap Hasil Belajar Matematika Dengan Mengontrol Intelegensi Siswa. Teknologi Pendidikan, Vol 5(1), 1-15. https://doi.org/https://doi.org/10.34005/akademika.v5io1

Muhlas, M., \& Marwani, L. (2020). Development of E-Learning Smart Apps Creator (SAC) Learning Media For Selling Employees on Paid TV. Akademika: Jurnal Teknologi Pendidikan, 9(02), 129-143.

Muhson, A. (2010). Pengembangan Media Pembelajaran Berbasis Teknologi Informasi. Jurnal Pendidikan Akuntansi Indonesia, 8(2). https://doi.org/10.21831/jpai.v8i2.949

Prasetyo, S. (2017). Pengembangan Media Pembelajaran IPA Berbasis Android Untuk Siswa SD/MI. Journal of Madrasah Ibtidaiyah Education, 1(1), 121-140.

Pribadi, R. B. (2017). Media dan Teknologi dalam Pembelajaran, Jakarta: Prenada Kencana. 
Rahmi D., \& M. PdK. (2019). The Influence Of Problem Based Learning Models And Learning Creativity On Initial Learning Outcomes And Entrepreneurship. Akademika : Jurnal Teknologi Pendidikan, 8(01), 35-45. https://doi.org/10.34005/akademika.v8io1.335

Widodo, I., \& Mukminan, M. (2018). Pengembangan e-learning mata pelajaran geografi untuk meningkatkan hasil belajar peserta didik kelas X SMA. Jurnal Inovasi Teknologi Pendidikan, 5(1), 12. https://doi.org/10.21831/jitp.v5i1.12534

Yusuf, I. 2016. Analisis Penggunaan Teknologi Informasi (Internet) Terhadap Masyarakat Di Kecamatan Sigi Biromaru Kabupaten Sigi. Katalogis. Jurnal Sosiologi Nusantara , 6(1), 45-53. https://core.ac.uk/download/pdf/327105227.pdf 